\title{
Medikamentell behandling av multippel sklerose
}

\author{
Multippel sklerose-attakker med signifikant funksjonssvikt skal \\ behandles med metylprednisolon. Ved gjentatte attakker og ved alvorlig \\ debuterende multippel sklerose er det indikasjon for forebyggende \\ behandling med interferon- $\beta$ /glatirameracetat (førstelinjebehandling), \\ natalizumab (annenlinjebehandling) eller mitoksantron (tredjelinje- \\ behandling).
}

Se også kunnskapsprøve på www.tidsskriftet.no/quiz

\section{Kjell-Morten Myhr}

kjell-morten.myhr@helse-bergen.no

Nasjonalt kompetansesenter for multippel sklerose

Nevrologisk avdeling

Haukeland universitetsykehus

5021 Bergen

Multippel sklerose er en kronisk inflammatorisk demyeliniserende sykdom i sentralnervesystemet. Den rammer unge voksne. Diagnosen stilles ved påvisning av disseminert sykdom (attakker og/eller progrediering) både i tid og lokalisasjon, basert på sykehistorie og klinisk nevrologisk undersøkelse, vanligvis supplert med MR-undersøkelse og ryggmargsvæskeanalyser (1-3).

I $80-90 \%$ av tilfellene debuterer sykdommen som attakkvis multippel sklerose (relapsing-remitting multiple sclerosis, RRMS), karakterisert ved gjentatte subakutte attakker med utfall fra sentralnervesystemet - med påfølgende varierende grad av remisjon (fig 1). Over tid vil en økende andel av pasientene utvikle sekundær progredierende multippel sklerose, etter 15-20 år ca. $50 \%$, med jevn progrediering, eventuelt med stabile faser, men uten remisjon $(1,2)$. Primær progredierende multippel sklerose $(10-20 \%)$ kjennetegnes av jevnt utviklende symptomer og utfall fra sentralnervesystemet, gjerne med stabile faser, men uten remisjon (fig 1).

Økende kompleksitet i terapitilbudet ved multippel sklerose har ført til bedre behandlingseffekt, men økt risiko for alvorlige bivirkninger. Behandlingen foregår $i$ hovedsak ved nevrologiske avdelinger, men krever økt kunnskap også hos fastlegene.

\section{Materiale og metode}

Den medikamentelle behandlingen inndeles vanligvis $\mathrm{i}$ attakkbehandling, forebyggende (sykdomsmodifiserende) behandling og symptombehandling. Her omtales status for attakkbehandling og forebyggende behandling. Grunnlaget for artikkelen er et ikkesystematisk litteratursøk i PubMed med et skjønnsmessig utvalg av artikler basert på forfatterens erfaring innen feltet.

\section{Attakkbehandling}

Attakkbehandling og forebyggende behandling har i all hovedsak en antiinflammatorisk effekt på sykdommen. Attakker (engelsk: relapse, exacerbation; tysk: Schub) og/eller kontrastladende MR-lesjoner i sentralnervesystemet er sikre tegn på inflammatorisk sykdomsaktivitet. I tillegg vil sikker økning av totalt antall MR-lesjoner sammenliknet med tidligere undersøkelser indikere inflammatorisk aktivitet i den aktuelle perioden. I praksis vil dette si at det er pasienter med attakkvis multippel sklerose som er tilgjengelig for behandling (2).

Attakkbehandling vurderes ved subakutte nye eller forverring av allerede eksisterende symptomer fra sentralnervesystemet. Vanligvis utvikles symptomene i løpet av timer til dager og vedvarer minst 1-2 døgn, gjennomsnittlig varighet er omtrent seks uker. Før behandlingen starter må man utelukke pågående infeksjon som årsak til forverring av sykdommen (4).

Attakker med klinisk signifikant funksjonsforverring behandles vanligvis med intravenøs infusjon av metylprednisolon (Solu Medrol), $1000 \mathrm{mg}$ per dag i 3-5 dager, ev. etterfulgt av peroral prednisolon $(60 \mathrm{mg}$ nedtrappet over to uker). Behandlingen gir raskere remisjon av attakket, men ikke mer fullstendig remisjon eller redusert risiko for nye attakker. Vanlige bivirkninger er dyspepsi og søvnproblemer, som kan forebygges med antacida og sovemedisin. Gjentatte behandlinger gir økt risiko for osteoporose, derfor bør beintetthetsmålinger gjennomføres og forebyggende behandling vurderes.

\section{Forebyggende behandling}

Ved ethvert attakk skal pasienten vurderes for oppstart eller endring av forebyggende behandling. Derfor bør all attakkbehandling skje i regi av eller i samråd med behandlende nevrolog/nevrologisk avdeling. Hensikten med forebyggende behandling er å redusere risikoen for nye attakker og bremse utviklingen av permanent funksjonssvikt $(2,5,6)$.

\section{Førstelinjebehandling}

Førstelinjebehandling er interferon- $\beta$ (Avonex, Betaferon, Extavia, Rebif), som er et cytokin, eller glatirameracetat (Copaxone), som består av syntetiske peptider med sekvenslikhet med myelin. Behandlingsindikasjonen er aktiv attakkvis multippel sklerose med gjentatte attakker. Ved omfattende klinisk utbredelse og/eller klare MR-forandringer startes behandling etter første attakk (clincal isolated syndrome, CIS). Interferon$\beta$-behandling kan også vurderes ved tidlig fase av sekundær progredierende multippel sklerose ved fortsatt attakkaktivitet.

Behandlingen gis som selvadministrerte injeksjoner, etter opplæring av spesialopplært sykepleier. Betaferon/Extavia gis subkutant $(250 \mu \mathrm{g})$ annenhver dag, Avonex intramuskulært $(30 \mu \mathrm{g})$ én gang per uke og Rebif subkutant $(44 \mu \mathrm{g})$ tre ganger per uke. Copaxone gis som daglige subkutane injeksjoner (20 mg). Pasienten får tett oppfølging av spesialopplært sykepleier de første månedene av behandlingen og hver 6 . måned hos nevrolog. Behandlingen reduserer risikoen for nye attakker med om lag $30 \%$, sykdomsaktiviteten, bedømt ved MR-undersøkelse, opptil $80 \%$ og utvikling av permanent funksjonssvikt opptil $40 \%$.

Behandlingen tolereres vanligvis godt, men de fleste (50-75\%) opplever oppstarts-

\section{Hovedbudskap}

- Moderate til alvorlige atakker med multippel sklerose skal behandles med metylprednisolon

- Ved gjentatte attakker skal pasienter behandles med forebyggende medikamenter

- Ved sviktende effekt av selvadministrerte injeksjonsmedikamenter til førstelinjebehandling finnes det annenog tredjelinjebehandling for intravenøs infusjon ved sykehus 


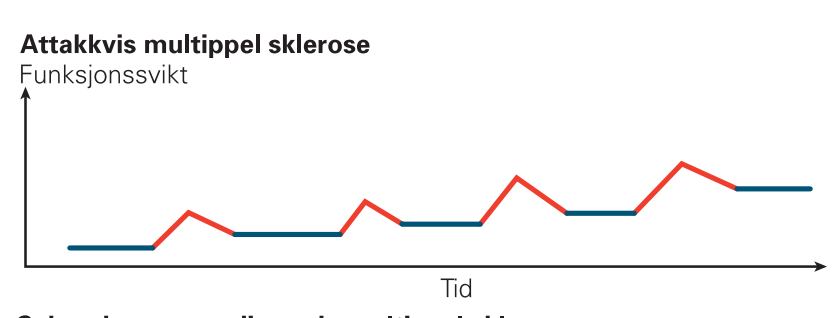

Sekundær progredierende multippel sklerose

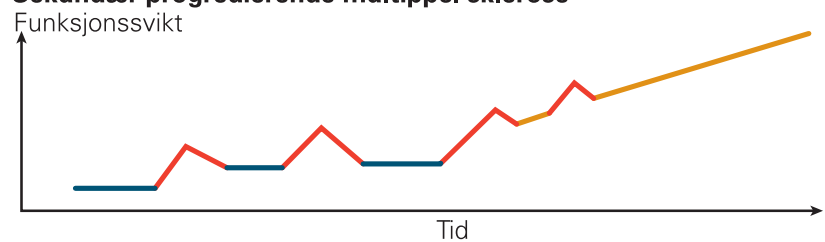

Primær progredierende multippel sklerose

Funksjonssvikt

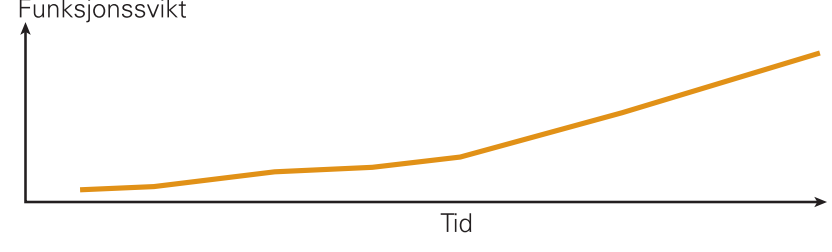

Figur 1 Sykdomsforløp ved multippel sklerose

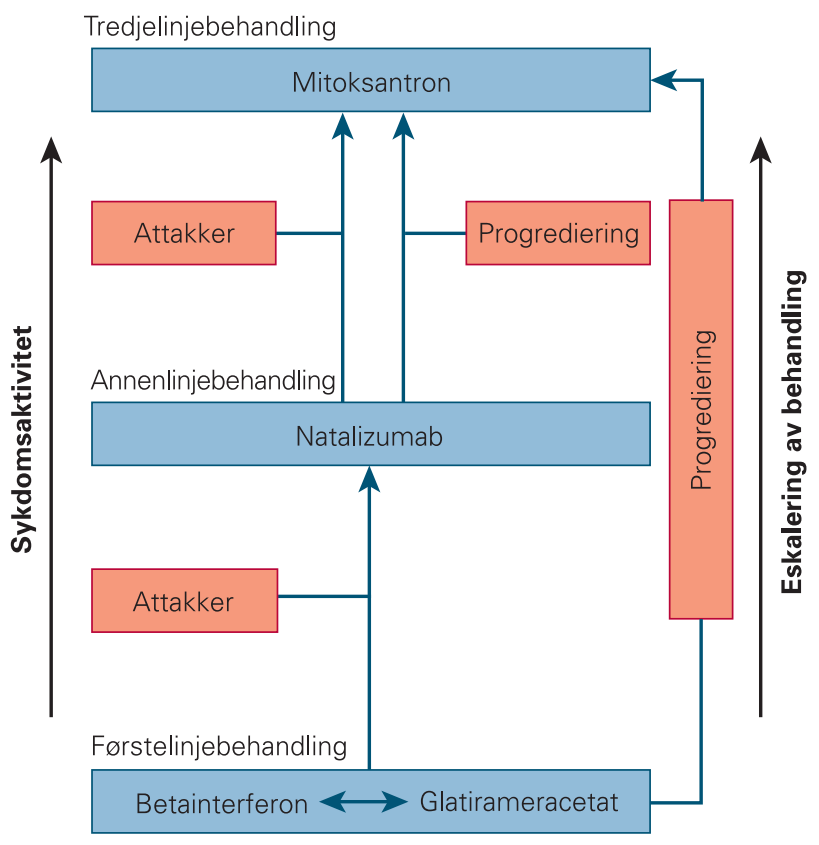

Figur 2 Forebyggende behandling ved multippel sklerose bivirkninger av interferon- $\beta$ med influensaliknende symptomer. Kveldsdosering og dosetitrering samt paracetamol og/eller ibuprofen kan redusere disse bivirkningene. Glatirameracetat kan gi en selvbegrensende og ufarlig postinjeksjonsreaksjon hos $10-15 \%$, med flushing, takykardi og dyspné. Andre glatirameracetatbivirkninger er lymfeknutesvulst, dyspné og subkutan lipoatrofi. Lokal reaksjon på innstikksstedet, med smerte, erytem og hevelse, er også relativt vanlig ved både interferon- $\beta$ og glatirameracetat. Sjeldne tilfeller av hudnekrose er rapportert. Systematisk rotering av injeksjonssted og steril prosedyre er viktig. Leverenzymstigning og beinmargsdepresjon kan oppstå ved bruk av interferon- $\beta$ og krever regelmessig oppfølging med blodprøvekontroller. Nøytraliserende antistoffer som hemmer behandlingseffekten kan dannes under interferon- $\beta$-behandling. Screening for nøytraliserende antistoffer er anbefalt etter 12 og 24 måneders behandling og ved tegn til terapisvikt $(7,8)$. Dette kan gjøres ved Nevro-Revma-Laboratorium, Haukeland universitetsykehus.

Effekten vurderes ut fra attakkrate og progrediering av permanent funksjonssvikt. I noen tilfeller kan også MR-undersøkelse være nyttig for terapievaluering. Ved gjentatte attakker på tross av optimalisert behandling må man vurdere et skifte mellom interferon- $\beta$ og glatirameracetat eller å gå over til annenlinjebehandling (fig 2).

\section{Annenlinjebehandling}

Annenlinjebehandling med natalizumab (Tysabri) er indisert ved gjentatte attakker på tross av førstelinjebehandling (9). Natali- zumab er et monoklonalt antistoff mot et adhesjonsmolekyl og hindrer sirkulerende aktiverte immunceller å migrere inn i sentralnervesystemet.

Midlet gis intravenøst (300 mg) én gang hver 4. uke og kan redusere risikoen for attakk med om lag $70 \%$, sykdomsaktiviteten, bedømt ved MR-undersøkelse, med $90 \%$ og utviklingen av permanent funksjonssvikt med $40-50 \%$. Bivirkningene er minimale, men det kan oppstå alvorlige allergiske reaksjoner. Det er også rapportert om virusencefalitt og flere tilfeller av progredierende multifokal leukoencefalopati (PML). Dette er en opportunistisk og potensielt dødelig infeksjon med JC-virus i sentralnervesystemet som kan oppstå hos ca. $0,1 \%$ av pasientene etter 18-24 måneders natalizumabbehandling. Symptomene kan forveksles med multippel sklerose-attakker. Dersom det oppstår mistanke om utvikling av progredierende multifokal leukoencefalopati, må behandlingen stoppes og MR-undersøkelse og ev. ryggmargsvæskeanalyser gjennomføres (10). Av samme årsak må de som tidligere har fått immunsupprimerende behandling gjennomgå en seks måneders utvaskingsperiode før oppstart med natalizumab, mens man kan gå fra førstelinjebehandling til natalizumabbehandling direkte.

Det kan også dannes nøytraliserende antistoffer mot natalizumab. Det anbefales screening etter seks og 12 måneders behandling og ellers ved mistanke om terapisvikt.

\section{Tredjelinjebehandling}

Tredjelinjebehandling med mitoksantron (Novantrone, Mitoxantron) kan vurderes hos dem som får gjentatte attakker under an- nenlinjebehandling eller hos dem som utvikler inflammatorisk aktiv sekundær progredierende sykdom uavhengig av pågående behandling (fig 2).

Mitoksantron er et cytostatikum som interagerer med nukleært DNA. Det har en potent immunsupprimerende effekt. Medikamentet er ikke registrert for behandling av multippel sklerose i Norge, men kan brukes i særlige tilfeller. Mitoksantron gis intravenøst, vanligvis $12 \mathrm{mg} / \mathrm{m}^{2}$ kroppsoverflate hver 3. måned eller som induksjonsbehandling dosert hver måned de første tre månedene og deretter hver 3. måned. Dosereduksjon gjøres ved sykdomsstabilisering. Behandlingen kan redusere attakkraten med opptil $70 \%$, progrediering av permanent funksjonssvikt og sykdomsaktivitet bedømt ved MR-undersøkelse. Vanlige bivirkninger er forbigående kvalme, fatigue og lettgradig hårtap dagene etter infusjonen. Leukopeni, som er en del av behandlingseffekten, må følges opp med blodprøvekontroller ved forventet laveste verdi, som inntreffer etter om lag ti dager. Alvorlige langtidsbivirkninger i form av hjertesvikt og terapiindusert leukemi kan oppstå. Derfor kreves det normal hjertefunksjon, bedømt ved ekkokardiografi, før oppstart. Dette må kontrolleres årlig under behandlingen. Blodprøvekontroller gjøres i oppfølging av hver dosering og før hver infusjon sammen med EKG. På grunn av risiko for alvorlige bivirkninger kan pasientene kun motta en maksimal akkumulert dose på $120-140 \mathrm{mg} / \mathrm{m}^{2}$ kroppsoverflate.

Ved fortsatt sykdomsaktivitet, attakker og/eller progrediering av funksjonssvikt på tross av første-, annen- og tredjelinjebehandling må man diskutere seponering av 
behandlingen eller inklusjon i pågående studier for utprøvende behandling eller annen eksperimentell behandling.

\section{Kostnader}

I 2008 var det ifølge reseptregisterert (11) registrert ca. 2500 brukere av førstelinjebehandling. For 2010 vil den årlige kostnaden utgjøre ca. 300 millioner kroner. Antall pasienter under annenlinjebehandling er langt færre, ca. 300 ved utgangen av 2009, men kostnaden per pasient er betydelig høyere. Behandlingen dekkes gjennom innsatsstyrt finansiering via de regionale helseforetakene. Dette fungerer utmerket hva gjelder pasientadministrert førstelinjebehandling. Derimot har annenlinjebehandling i sykehus ikke tilstrekkelig dekning gjennom denne ordningen og generer betydelige underskudd ved enkelte sykehusavdelinger.
Oppgitte interessekonflikter: Forfatteren har deltatt $i$ behandlingsstudier og mottatt undervisningshonorar og/eller reisestøtte til vitenskapelige kongresser fra Bayer Schering Pharma, Biogen Idec, GlaxoSmithKline, Merck Serono, Novartis og sanofi-aventis.

\section{Litteratur}

1. Compston A, Coles A. Multiple sclerosis. Lancet 2008; 372: 1502-17

2. Myhr KM. Diagnosis and treatment of multiple sclerosis. Acta Neurol Scand 2008; 188: 12-21.

3. Polman $\mathrm{CH}$, Reingold $\mathrm{SC}$, Edan $\mathrm{G}$ et al. Diagnostic criteria for multiple sclerosis: 2005 revisions to the «McDonald Criteria». Ann Neurol 2005. 58: 840-6.

4. Myhr KM, Mellgren SI. Corticosteroids in the treatment of multiple sclerosis. Acta Neurol Scand 2009; 189: 73-80.

5. Rieckmann P Toyka KV Bassetti $C$ et al. Escalating immunotherapy of multiple sclerosis - new aspects and practical application. J Neurol 2004; 251: 1329-39

6. Wiendl H, Toyka KV, Rieckmann P et al: Multiple Sclerosis Therapy Consensus Group. Basic and escalating immunomodulatory treatments in mul- tiple sclerosis: current therapeutic recommendations. J Neurol 2008: 255: 1449-63.

7. Sørensen PS, Deisenhammer F, Duda P et al. Guidelines on use of anti-IFN-beta antibody measurements in multiple sclerosis. Eur J Neurol 2005; 12: 817-27.

8. Aarskog NK, Marøy T, Myhr KM et al. Antibodies against interferon-beta in multiple sclerosis. J Neuroimmunol 2009: 212: 148-50.

9. Bekkelund SI, Dietrichs E, Celius EG et al. Behandling av multippel sklerose (MS) med natalizumab. Oppstart, gjennomføring og avslutning av behandling. Oslo: Helsedirektoratet, 2007.

10. Kappos L, Bates D, Hartung HP et al. Natalizumab treatment for multiple sclerosis: recommendations for patient selection and monitoring. Lancet Neurol 2007; 6: 431-41.

11. Reseptregisteret. www.reseptregisteret.no/ (4.1.2010).

Manuskriptet ble mottatt 20.9. 2009 og godkjent 7.1. 2010. Medisinsk redaktør Petter Gjersvik 